\title{
講演会「文化財建造物の耐震診断と 維持管理技術の最前線」に参加して
}

\section{はじめに}

(財)建築研究協会主催の講演会「文化財建造物の 耐震診断と維持管理技術の最前線」が, 去る 6 月 12日に京都市国際交流会館にて開催された。本講 演会では，住宅などの建築物の耐震診断や耐震改 修が普及しつつある昨今において, 寺院や町屋な どの伝統構法による木質建造物の耐震診断や改修 に関する技術開発や, 腐朽や虫害などの木質の劣 化の診断や維持管理技術に関する知見が, 各講演 者によって紹介された。会場には, 文化財建造物 に関する講演会ということもあり, 興味深い内容 に100名を超える多くの参加者が集まった。本講演 会は, (財)建築研究協会理事の京都大学名誉教授の 西本孝一先生によるご挨拶で始まり, 大阪大学大 学院工学研究科教授の甲津功夫先生の司会進行の もと, 講演は 3 題行われ（2題目は，2つのパー トに分かれている), 講演後に行われた総合討論で は，熱心な質疑応答がなされた。以下に演題と講

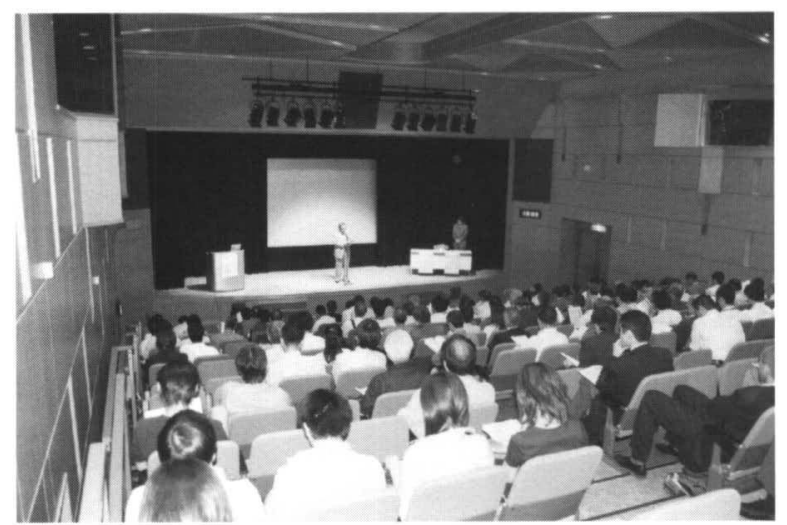

写真 1 京都大学名誉教授の西本孝一先生による開 催の挨拶

\section{箈 瀬 佳 之*}

演者を紹介すると共に，それぞれの講演内容につ いて紹介したい。

\section{1. 伝統的木質構造物の耐震性能と耐震診断}

京都大学防災研究所 教授 鈴木祥之氏 近年, 兵庫県南部地震をはじめ, 大地震によっ て，木造建築物は甚大な被害を受けており，多く の死傷者を出す原因となった。また近い将来にも 大地震の発生が予想される中, 十分な安全性を確 保できていない木造建築物も多いことから，伝統 構法木造建築物の耐震性能の確保 - 向上が重要な 課題となっている。その中で, 伝統建築物の保存 . 再生において構造的な観点からの研究が少ないこ と, また複雑な構造のために, 構造力学的な解明 が十分されておらず, 伝統構法木造建築物の耐震 性は, 実際のところよくわかってないのが現状で ある。阪神・淡路大震災以後, 1998年に建築基準 法が改正されたことにより, 伝統構法木造建築物 の耐震安全性が重視され, 既存建物では, 耐震性 能評価に基づいた耐震診断法および耐震補強法の 開発が急務となっている。このような背景のもと， 鈴木氏は, 木造建築物の地震被害調査などと共に 各地域における伝統木造建築物の構法的特徴と構 造特性を把握し, 各種の耐震要素をはじめ, 実大 の伝統木造建築物の静的 ・動的実験に基づく, 伝 統構法木造建築物の耐震性能評価法や耐震設計 法 - 耐震補強設計法の考え方と, 伝統構法木造建 築物の静的実験, 振動台実験による耐震性能評価 法や耐震補強法の検証について紹介した。

伝統構法の木造建築物は, 木材と木組みの粘り 強い特性を生かして耐震性能を発揮するもので, 
それほど大きな耐力はないが, 大きな変形性能を もち, 耐力と変形性能の両者を考慮して耐震性能 を評価することが重要であると指摘し,「限界耐力 計算」に基づく耐震性能評価や耐震設計法を提唱 している。東本願寺の御影堂建物の耐震性能評価 と耐震補強設計を事例として紹介しており, 限界 耐力計算によって耐震性能を評価した結果, 屋根 の葺土を大幅に軽減して建物重量を軽減すること により，建物の水平耐力の向上が見达まれること が検証された。そして, 耐震性能を評価し, 耐震 補強としては, 屋根重量の軽減と, 外周三方の小 壁の耐力・変形性能の向上と西側土壁による偏心 の改善を図ることによって, 極めて稀に発生する 地震動に対して安全限界変形角に収まる結果とな ったことを報告している。また伝統構法木造住宅 の耐震性能評価では, クレーン車を用いて, 大変 形加力実験を行うとともに, 木部の強度劣化測定 や他の劣化診断も同時に行っている。静的加力実 験では柱に損傷を生じたものの大破・倒壊には至 らず，大きな変形性能を保持していることが示さ れ，さらに限界耐力計算による耐震性能評価を試 みた場合, 劣化部分を考慮することによって, 静 的実験の結果とほほ一致したことから, 劣化の著 しい部分を補修することで，大地震に対しても耐 震性能を確保できるという結果が得られている。

やはり,木造建築物の耐震性能を評価する上で, 生物劣化というものを考慮して計算する方法の確 立も今後の課題の一つになるのではないだろうか と思う。

\section{2. 文化財に見られる生物劣化と診断およ び維持管理}

\section{（1） 木材の生物劣化現象とその機構}

京都大学生存圈研究所 教授 今村祐嗣氏 建造物で使用される木材は, 燃える, 狂う, 虫 に食われる，腐るという欠点を持っており，適切 な維持管理が行われていない建造物では, 虫害や 腐朽といった生物劣化が, 大地震の際に建造物の 倒壊などの被害を甚大化させる可能性がある。文 化財建造物においても木材の生物劣化は常につき まとうものであり, この生物劣化現象とその機構 を理解することが，文化財建造物を長期にわたっ て維持管理して行く上で非常に重要になってく

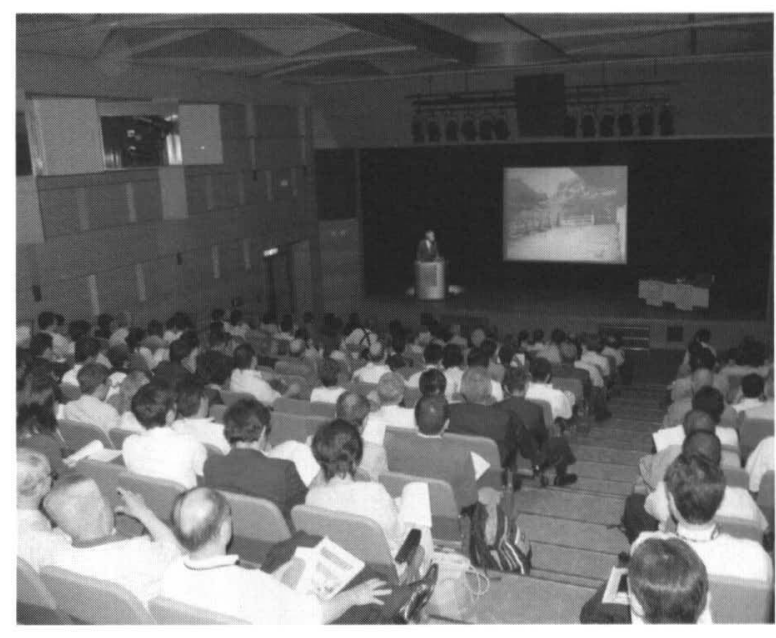

写真 2 講演の様子

る。今村氏は, 木材に劣化を引き起こす主要なも のとして, 腐朽やシロアリ等による生物劣化現象 とその機構について, 基礎的な研究結果から実際 の生物劣化の事例に至るまで, 幅広く, わかりや すく紹介している。木材腐朽菌にとって, 温度, 酸素, 水分が重要な因子であり, 特に水分条件は 劣化の危険性と深く関連し, 建造物の設計と維持 管理を適切に行うことにより，腐朽菌による生物 劣化の危険度を低減することが可能であると指摘 している。特に文化財建造物は雨水に暴露される 可能性が高く, このことが劣化の大きな引き金と なることや，また被覆された建造物内部でも漏水 や結露によって腐朽が発生することを紹介してい る。代表的な木材腐朽菌である「白色腐朽菌」と 「褐色腐朽菌」によって腐朽した木材の曲げ強度 は, 重量減少とともに低下し, 特に褐色腐朽菌で は, わずかな質量減少でも木材の強度低下が大き いことが紹介された。

腐朽菌と同様に木材の生物劣化の代表であるシ ロアリについては, その生態的な特徴を紹介する とともに, 飭となる木材の種類によって被害は異 なるが, 心材に比べて, 辺材部分は, どの樹種で も食害される可能性があることから, 文化財建造 物で使用する木材の選定にも注意を払わなければ ならないと思う。

\section{（2）診断・点検に基づく維持管理のすすめ}

京都大学大学院農学研究科

准教授 藤井義久氏

文化財建造物は, 規模, 技術, コストなどの制 
約により，解体修理や半解体修理などの大規模な 修理は長周期的に実施されることがほとんどであ り，虫害や腐朽に対する劣化対策も同時期に実施 される。しかし，劣化対策は実際には数十年も長 持ちすることはなく，また長期間放置されること によって,生物劣化による甚大な被害が発生する。 このような背景から，藤井氏は，文化財建造物の 保存修復の現状, 文化財建造物における生物劣化 の特徵, 生物劣化診断・点検による文化財建造物 の維持管理，さらには劣化診断と耐震診断との関 連性について紹介している。

本来, 文化財建造物は地震に強い木質構造物で 構築されているが, 維持管理状態が悪く（短い周 期で劣化対策が行われていない)，腐朽や虫害など の生物劣化が弱点になって, 地震による被害が甚 大になっている場合が多い之指摘している。そし て, 特に文化財建造物の生物劣化の特徴として, 長期間放置による劣化の甚大化，大規模建造物で あるがゆえに, 全体の生物劣化の把握ができない， 劣化対策からみて工法や使用する材料に無理があ る, 材料の調達事情, 材料管理, 施工管理などの 変化などをあげている。このような特徵をもった 生物劣化に対して, 文化財建造物を維持管理して いくためには，これまでの長周期的な大規模改修 サイクルから，短周期の点検と小規模補修サイク ルへの見直しと, 生物劣化の早期発見・早期対策 による文化財建造物の維持管理の最適化を提案し ている。そして, 生物劣化の検出とその評価方法 について，具体的には腐朽菌や木材拱食昆虫の直 接的・間接的な検出, 劣化による木材の物性变化 の評価, 劣化促進環境の評価, の 3 項目をとりあ げ，特に耐震診断とも関わりのある木材の物性変 化の評価方法として, 衝撃ピンの打ち込み（ピロ ディン）と穿孔抵抗測定器（レジストグラフ）を 用いた測定事例を紹介している。

これまで耐震診断と劣化診断は, 別々の診断で あると考えていたが，文化財建造物の維持管理に おいて，なるべく短周期で劣化診断を行い，必要 であれば生物劣化の対策（駆除や予防）と建造物 の補修・補強を行った上で，劣化診断で得られた データをもとに, 耐震診断・耐震性能評価を行う ようなシステムが構築されれば，膨大なコストと 時間をかけずとも十分な保存・修復が可能になる
だろう。

\section{3. 重要文化財 清水寺奥院舞台の耐震対 策について}

\author{
京都府教育庁 指導部文化財保護課 \\ 文化財専門技術員 鶴岡典慶氏
}

文化財建造物は建築基準法の適用が除外されて いるため，具体的な法規制はないが，解体修理等 大規模な修理を行う際には，現行基準に準じた耐 震性能を有したものとなるよう取り組みが進めら れている。しかしながら，未だ構造診断が実施さ れていないものも少なくない。その中でも特に観 光客等が訪れる社寺や民家等の文化財建造物につ いては，耐震診断を実施し，対策を講じておく必 要がある。鶴岡氏は，この耐震診断と耐震対策に ついて，実際に行われた清水寺奥院の舞台の耐震 診断と耐震対策工事を事例として紹介し，特に耐 震対策の内容を中心に報告している。奥院は，建 物の前面が舞台造になっており，建物本体は平坦 地に建つが，舞台は斜面上に㲘け出されて造られ ている。したがって, 奥院舞台の耐震診断の対象 としては，傾斜地の地盤とその上部構造物の二つ の要素があるため,それぞれ個別に診断を実施し， 設計時に双方の必要な補強項目を照合していく方 法を用いている。地盤表層の風化・侵食防止策と して，斜面全体にプレート付アンカーを挿入して 表土を支持した上で，表層面保護として連続緎維 補強土と厚層基材を吹き付けて仕上げている。

上部構造物の耐震診断では, 文化庁からの重要 文化財の耐震診断指針に示される，「機能維持水 準」,「安全確保水準」,「復旧可能水準」の三区分 のうち，文化財的価值を損なうことなく，また柱 と貫だけの構造が比較的大きな変形が生じても追 随可能な構造であることを考慮した上で,「安全確 保水準」に基づいて耐震診断を行っている。診断 結果より, 大地震時において, 梁行方向では貫に かかる軸力で柱から貫が移動し, 楔が抜け出す可 能性があり，桁行方向では貫断面が小さくなった り，継手が簡略化されたこともあり，水平耐力が 不足しているために倒壊する可能性があると判定 している。この結果をもとに, 補強計画を立てて いくわけだが，この建物の特徽である柱と貫だけ の構造美を重視することが前提であり，そのため 


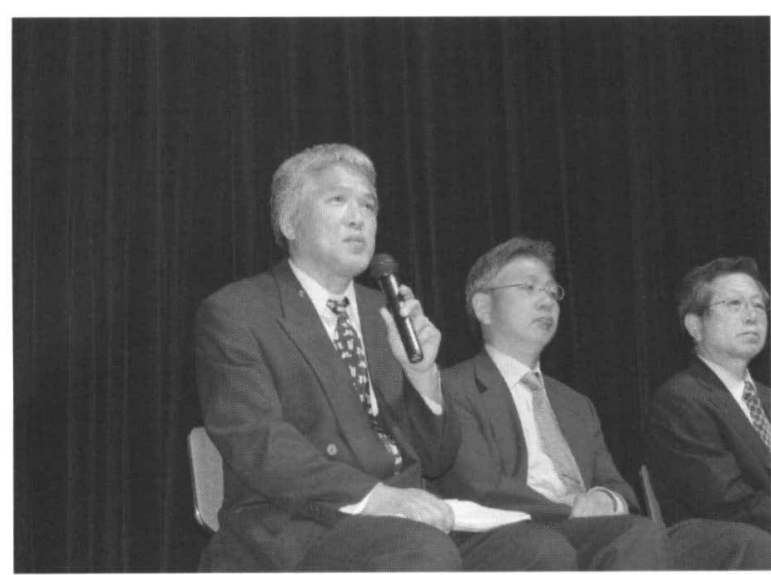

写真 3 講演後の総合討論の様子

に，梁行方向は身舎前面地盤にアンカーを打ち， 床下大引と緊結して, 地震時に生じる軸力を地盤 面で支持させるようにし，柱と貫に補強を行う必 要をなくした。また桁行方向は貫断面や継手等を 当初の形状に復することにより, 柱と貫の回転剛 性を向上させるとともに，柱足元と礎石等の接合 部が外れることによる架構の倒壊を防止するため に,鉄やステンレスを使用して補強を行っている。 近年, 文化財建造物の解体や半解体等の根本修 理に際して, 耐震診断は必須のものとして組み入 れられ検討されていているが, これらの成果が他 の診断等に活用されている例が少ないとも報告し ている。文化財建造物はそれぞれが異なった構造 をしていることから，その建物を対象とした診断 や実験結果をそのまま他の建造物に利用すること はできないかもしれないが, ある程度の部分（建
造物の強度目標, 強度解析の手法, 補強方法など） までは情報のネットワーク化を行うことで, 今後, 複雑な伝統構法木造建築物の構造性能の解明にも 利用できるのではないかと思う。

\section{おわりに}

以上，極めて簡単ではあるが，(財建築研究協会 主催の講演会「文化財建造物の耐震診断と維持管 理技術の最前線」について報告した。今回の講演 会は, 伝統的木質建築物の耐震診断や劣化診断の 技術を融合した新しい診断技術と建築物の改修に 関する技術の研究への先駆けとして開催されたも のであり, 今後の研究の進展に期待を抱かせるよ うな，とても有意義な講演会であった。最後にな ったが, 本講演会の開催準備に努めていただいた 関係者の方々と, 講演者の方々に厚く御礼申し上 げる。

なお, 写真は全て京都大学大学院農学研究科の 藤原裕子氏に提供していただいた。

私はこの体験記を執筆した翌日から，7月16日 午前に発生した新潟県中越沖地震によって倒壊し た木造建造物の生物劣化と構造材の接合部に関す る調査研究のために, 新潟県柏崎市へ向かうこと になったが，今回の講演会で得られた耐震性能・ 補強と生物劣化に関する様々な視点からのアプ ローチを参考に, 調査研究を進めていきたいと思 っている。

(2007. 8.29受付) 